\section{New impetus for French AIDS health education campaign}

\section{Paris}

FACED with a projected 10,000-15,000 declared cases of AIDS (acquired immune deficiency syndrome) in 1989, France is to step up its health-education campaign and provide more facilities for the care of AIDS sufferers. During a cabinet briefing on 20 January, Health Minister Michéle Barzach told ministers that FF930 million ( $\$ 165$ million) had been set aside in 1988 for prevention, education and health care. Barzach also reported on the success of the existing measures (see Nature 328, 3; 1987) and announced new initiatives.

At the end of last year, 3,073 cases of AIDS had been recorded in France, including its overseas territories, of whom 45 per cent had already died. known cases were in the Paris region (58 per cent) and southern France, around Marseilles, Toulon and Nice. Barzach put at 150,000200,000 the number of individuals infected by the human immunodeficiency virus (HIV), but not showing symptoms of AIDS.

Among the public health measures undertaken so far, Barzach mentioned the mandatory, anonymous notification of all AIDS sufferers; the availability to all of anonymous screening; the systematic screening of donors of organs or sperm; the establishment of 11 information and care centres; the signing of a legal agreement between the US Department of Health and Human Services and the Institut Pasteur ending the patents dispute over the antibody test; the deregulation of public advertising of condoms; and the availability, without prescription, of hypodermic syringes. In addition, the antiviral agent AZT is to be released into

Since the start of the campaign, there has been a 38 per cent increase in sales of condoms in pharmacies and a marked increase in demand for screening tests. In 1987, 2.3 million ELISA (enzyme-linked immunosorbent assay) tests were sold in France, compared with 800,000 in 1986 . Encouraged by these "very positive" results, Barzach noted that each French department would have a free screening centre this year.

In addition to the 11 existing AIDS clinics and advice centres, a further 11 are to be opened, two of them in overseas departments, French Guiana and the Antilles. Barzach also aims to ask general practitioners to play a bigger role by encouraging patients to be screened at ' $\mathrm{key}$ moments' in life, such as marriage and pregnancy.

Peter Coles - Ten haemophiliacs suffering from AIDS have joined together in a legal fight for compensation against the French national blood transfusion service (CNTS). They claim that CNTS continued to supply contaminated blood for "several months" during 1985, even though treated imported supplies from other European countries and the United States were available. the market.

\title{
Bavarian government maintains reputation for AIDS controversy
}

\section{Munich}

THE appointment of Michael Koch, a Swedish physician, by the Bavarian Interior Ministry on 1 January to develop publicity material concerning AIDS (acquired immune deficiency syndrome) has precipitated a row in the West German Bundestag.

The Social Democratic Party (SPD) claimed that Koch's testimony before a Bundestag panel in September was "a mixture of 80 per cent irresponsible and unbelievable claims and 20 per cent scientifically sound views". Koch's appointment was also condemned by members of the Green Party and of the Christian Democrats (CDU).

Koch is to receive about DM100,000 in 1988 for his work. He is expected to pro-

\section{Correction: French research}

There are 270 posts available at CNRS in 1988 of which 150 are new posts (see Nature 331, 200; 1988). duce easy-to-understand pamphlets about AIDS for health officials. Bavarian Interior Ministry spokesman Christoph Hillenbrand vigorously denied that Koch would serve as a policy adviser.

Koch was accused by his opponents of calling for the internment of carriers of the human immunodeficiency virus (HIV) who do not behave "reasonably", such as prostitutes who do not use condoms. Hillenbrand pointed out that Koch would advise such measures "only as a last resort". But "isolation" would be in keeping with the federal law on epidemics, said Hillenbrand.

Bavaria has been a source of controversy over AIDS since early last year, when it began to test immigrants from outside the European Community for HIV and to refuse entry to carriers. The Bavarian AIDS programme has been rejected by West German Health Minister Rita Süssmuth (CDU). Steven Dickman

\section{US nuclear waste site "unsuitable"}

\section{Las Vegas, Nevada}

Nevada Governor Richard Bryan claimed on 21 January that the Department of Energy (DoE) intentionally suppressed a study by a government scientist that raises serious questions about the suitability of Yucca Mountain as the site for the nation's first high-level nuclear waste repository.

Bryan said the study of water flows in the Death Valley system by DoE scientist Jerry S. Szymanski was given to the Energy Department in November, a month before Congress chose Yucca Mountain, 80 miles north-west of Las Vegas, as the national nuclear repository.

Szymanski said that underground pressure from volcanic and seismic activity may force corrosive water within the mountain's tuff through cracks and fissures, eventually leading into the repository where nuclear containers could corrode.

Szymanski, the governor said during a press conference, expressed concern to DoE superiors as early as 1984 . Carl Gertz, Nevada Nuclear Waste Project Manager said DoE asked Szymanski to prepare his report in November last year, knowing how he felt about Yucca Mountain. Gertz said he received the report on 22 December.

Szymanski's report recommends a thorough review of 10 years of data concerning water flow at Yucca Mountain, complete investigation of rocks marked by water and chemical analysis of the water in the rocks and soil. Mary Manning

Second AIDS trial Washington

THE US National Institutes of Health (NIH) and the biotechnology company MicroGeneSys have announced another clinical trial of their jointly developed vaccine against AIDS. The vaccine, which consists of the gp160 envelope protein from HIV, the virus causing AIDS, is to be administered to 72 healthy seronegative male and female volunteers at six federally sponsored Vaccine Evaluation Units.

The first clinical trial of the vaccine that began in October involving homosexual men will continue. But so far only 31 volunteers out of the 81 required have been found (see Nature 327, 687; 1987).

The six Vaccine Evaluation Units - at Baylor College of Medicine in Houston, Texas; Johns Hopkins University and the University of Maryland in Baltimore, Maryland; Vanderbilt University in Nashville, Tennesee; Marshall University in Huntington, West Virginia; and the University of Rochester in Rochester, New York - will recruit volunteers locally. Two test groups will receive differing dosages of the actual vaccine, and control groups will receive either recombinant hepatitis $B$ vaccine or the adjuvant alum. Carol Ezzell 